\title{
PENGARUH REALISASI PENDAPATAN ASET DAERAH, DANA PERIMBANGAN DAN LAIN-LAIN PENDAPATAN DAERAH YANG SAH TERHADAP BELANJA MODAL PEMERINTAH KABUPATEN BARITO TIMUR
}

\author{
Andi Suparta \\ Sekolah Tinggi Ilmu Ekonomi Pancasetia Banjarmasin \\ Jl. Ahmad Yani Km. 5.5 Banjarmasin \\ e-mail : andisuparta93@gmail.com
}

\begin{abstract}
The aims of this research is to determine the effect of local revenue realization, balancing funds and other legitimate regional revenues on the capital expenditure of the East Barito District Government. The source of this research data is the Financial Report of the East Barito District Government for 10 (ten) years 2010 to 2019. Data analysis techniques using classic assumption test and multiple linear regression analysis using SPSS version 24 for windows. The results of the study show that simultaneous regional assets revenues, considerations fund and other legitimate regional revenues affect capital expenditure. Partially regional assets revenues, considerations fund and other legitimate regional revenues affect the capital expenditure of the East Barito District Government. While the Regional asset revenues has a dominant effect on capital expenditure in the East Barito Regency Government.
\end{abstract}

Key words : Regional asset revenues, considerations fund, other legitimate regional revenues, capital expenditure.

Abstrak : Penelitian ini bertujuan untuk mengetahui pengaruh realisasi pendapatan
asli daerah, dana perimbangan dan lain-lain pendapatan daerah yang sah terhadap
belanja modal Pemerintah Kabupaten Barito Timur. Sumber data penelitian ini adalah
Laporan Keuangan Pemerintah Daerah Kabupaten Barito Timur selama 10 (sepuluh)
tahun 2010 sampai 2019. Teknik analisis data menggunakan analisis uji asumsi klasik
dan analisis regresi linear berganda dengan menggunakan program SPSS versi 24 for
windows. Hasil penelitian menunjukkan bahwa secara simultan pendapatan asli
daerah, dana perimbangan dan lain-lain pendapatan daerah yang sah berpengaruh
terhadap belanja modal. Secara parsial pendapatan asli daerah, dana perimbangan dan
lain-lain pendapatan daerah yang sah berpengaruh terhadap belanja modal Pemerintah
Kabupaten Barito Timur. Pendapatan Asli Daerah berpengaruh dominan terhadap
belanja modal pada Pemerintah Kabupaten Barito Timur.

Kata kunci : Pendapatan asli daerah, dana perimbangan, lain-lain pendapatan daerah yang sah, belanja modal. 


\section{Latar Belakang}

Pemberian otonomi yang luas dan desentralisasi membuka jalan bagi pemerintah untuk melakukan pengelolaan keuangan daerah yang berorientasi pada kepentingan publik. Pasal 4 ayat 1 Peraturan Menteri Dalam Negeri (Permendagri) Nomor 13 Tahun 2006 tentang Pedoman Pengelolaan Keuangan Negara menegaskan bahwa pengelolaan keuangan daerah harus dilakukan secara tertib, taat pada peraturan perundangundangan yang berlaku, efisien, efektif, transparan, dan bertanggung jawab dengan memperhatikan asas keadilan, kepatutan, dan manfaat untuk masyarakat. Kemampuan daerah dalam mengelola keuangan dituangkan dalam Anggaran Pendapatan dan Belanja Daerah (APBD) yang langsung maupun tidak langsung mencerminkan kemampuan pemerintah daerah dalam membiayai pelaksanaan tugas-tugas pemerintahan, pembangunan, dan pelayanan sosial masyarakat. Berkaitan dengan hakikat otonomi daerah yaitu pelimpahan wewenang dalam pengambilan keputusan/kebijakan, pengelolaan dana publik, dan pengaturan kegiatan dalam rangka penyelenggaraan pemerintahan dan pelayanan masyarakat maka peranan data keuangan daerah sangat dibutuhkan untuk mengidentifikasikan sumber-sumber pembiayaan daerah serta jenis dan besaran belanja yang harus dikeluarkan agar perencanaan keuangan dapat dilaksanakan secara efektif dan efisien.

Maka perlu ditegaskan bahwa pelaksanaan otonomi daerah tidak hanya terfokus kepada dana bantuan dari pusat dalam bentuk dana perimbangan saja. Lebih penting dari itu adalah bagaimana kemampuan daerah untuk memanfaatkan dan mendayagunakan, serta mengelola potensi-potensi yang ada di daerah dalam rangka meningkatkan pelayanan publik kepada masyarakat dan pembangunan daerah. Menurut Permendagri No 59 Tahun 2007 tentang perubahan atas Permendagri No 13 Tahun 2006 tentang Pedoman Pengelolaan Keuangan Daerah diungkapkan pengertian belanja daerah yaitu kewajiban pemerintah daerah yang diakui sebagai pengurang nilai kekayaan bersih. Dari pengertian tersebut dapat disimpulkan bahwa belanja daerah adalah semua pengeluaran pemerintah daerah pada satu periode anggaran yang berupa arus aktiva keluar guna melaksanakan kewajiban, wewenang, dan tanggung jawab kepada masyarakat dan pemerintah pusat.

Permendagri No. 13 Tahun 2006 tentang Pedoman Pengelolaan Keuangan Daerah pasal 50 menjelaskan bahwa kelompok Belanja Langsung pemerintah daerah terdiri dari tiga komponen, yaitu: 1) Belanja Pegawai, 2) Belanja Barang dan Jasa, dan 3) Belanja Modal. Belanja Modal menurut Peraturan Pemerintah Nomor 58 Tahun 2005 merupakan pengeluaran yang dilakukan dalam rangka pembelian atau pengadaan aset lainnya yang mempunyai masa manfaat lebih dari 12 (dua belas) bulan untuk digunakan dalam kegiatan pemerintahan, seperti dalam bentuk tanah, peralatan dan mesin, gedung dan bangunan, jaringan, buku perpustakaan dan hewan. Mardiasmo (2004: 187) menjelaskan bahwa Belanja Modal adalah Belanja Langsung yang digunakan untuk membiayai kegiatan investasi (menambah aset). Belanja Modal merupakan komponen Belanja Langsung dalam anggaran pemerintah yang menghasilkan output berupa aset tetap yang dalam pemanfaatan aset tetap tersebut ada yang bersinggungan langsung dengan pelayanan publik dan ada yang tidak dimanfaatkan langsung oleh publik. Pemanfaatan aset tetap yang bersinggungan langsung dengan pelayanan publik diantaranya adalah jalan raya, jembatan, trotoar, rambu lalu lintas, dan stadion atau gedung olahraga.

$$
\text { Belanja Modal merupakan }
$$

komponen Belanja Langsung dalam anggaran pemerintah yang menghasilkan output berupa aset tetap yang dalam pemanfaatan aset tetap tersebut ada yang bersinggungan langsung dengan pelayanan publik dan ada yang tidak dimanfaatkan langsung oleh publik. Pemanfaatan aset tetap yang bersinggungan langsung dengan pelayanan publik diantaranya adalah jalan 
raya, jembatan, trotoar, rambu lalu lintas, dan stadion atau gedung olahraga. Pemanfaatan aset yang tidak berhubungan langsung dengan pelayanan publik atau tidak dimanfaatkan langsung oleh publik yaitu seperti gedung kantor pemerintahan. Sejalan dengan pembaharuan peraturan yang mendasari pengelolaan keuangan daerah yaitu dengan diamandemennya UU No. 22 Tahun 1999 menjadi UU No. 32 Tahun 2004, kemudian diikuti dengan amandemen PP No. 105 Tahun 2000 menjadi PP no. 58 Tahun 2005, dan amandemen Kepmendagri No. 29 Tahun 2005 menjadi Permendagri No. 13 Tahun 2006, pengalokasian sumber daya ke dalam Belanja Modal (Capital Expenditures) sebenarnya dimaksudkan untuk memenuhi kebutuhan publik akan sarana dan prasarana umum yang disediakan oleh pemerintah daerah.

Realisasi Belanja Operasi dan Belanja Modal pemerintah Kabupaten Barito Timur dari tahun 2010 sampai dengan 2019 adalah pada tahun 2010 sampai dengan tahun 2017 proporsi belanja operasi sekitar $80 \%$ namun di tahun 2018 dan 2019 hanya $70 \%$ sedangkan proporsi persentase untuk Belanja Modal sekitar $20 \%$ kecuali di tahun 2018 dan 2019 lebih tinggi yaitu diatas $25 \%$. Perkembangan belanja modal secara keseluruhan dari tahun 2010-2019 di Kabupaten Barito Timur tidak terlalu mengalami grafik yang signifikan hal ini disebabkan proporsi anggaran untuk belanja modal setiap tahun tidak mengalami peningkatan terus menerus tetapi fluktuatif. Menurut konsep Multi-Term Expenditure Framework (MTEF), kebijakan Belanja Modal harus memperhatikan kemanfaatan (usefullnes) dan kemampuan keuangan pemerintah daerah (budget capability) dalam pengelolaan aset dalam jangka panjang (Allen dan Tommasi, 2001). Saragih (2003) menyatakan bahwa pemanfaatan Belanja Modal hendaknya dialokasikan untuk halhal yang produktif seperti pembangunan. Darmawanto dan Yustikasari (2007) menjelaskan bahwa penerimaan pemerintah hendaknya lebih banyak untuk programprogram pelayanan publik.

Pemerintah pusat terus mendorong pemerintah daerah agar persentase Belanja Modal terus ditingkatkan mulai dari $24 \%$, kemudian 26-27\% hingga pada tahun 2014 menjadi $30 \%$ (Ditjen Bina Keuangan Daerah, 2013). Meskipun pemerintah pusat telah mendorong untuk meningkatkan pengalokasian Belanja Modal, namun realitasnya persentase Belanja Modal dalam pelaksanaannya memiliki kecenderungan yang semakin menurun jika dibandingkan dengan total belanja daerah (Halim, 2014: 226). Belanja Modal untuk pemerintah Kabupaten Barito Timur dari analisis data diatas dari tahun 2010- 2017 persentase untuk belanja modal masih rata-rata $20 \%$ sedang untuk tahun 2018-2019 mencapai $27 \%$ sehingga masih belum dapat memenuhi arahan pemerintah pusat tersebut dikarenakan belanja modal masih ketergantungan dari dana transfer.

Berdasarkan pada teori dan kondisi yang berkembang pada saat ini pada pertumbuhan suatu daerah maka perlu dilakukan penelitian empirik yang menganalisis lebih mendalam dalam menguji pengaruh Pendapatan Asli Daerah, Dana Perimbangan dan Lain-lain Pendapatan Asli Daerah yang sah terhadap Belanja Modal Pemerintah Kabupaten Barito Timur selama 10 (sepulu) tahun dari 2010 sampai dengan 2019. Fenomena yang terjadi juga di Satuan Kerja Perangkat Daerah (SKPD) di Kabupaten Barito Timur pada tahun-tahun tertentu didalam perencanaan untuk belanja modal tidak dianggarkan karena masih minim nya dana, dan masih ketergantungan dari dana transfer, kondisi yang terjadi menjadi tantangan SKPD terkait untuk lebih lagi menggali potensi Pendapatan Asli Daerah dan bisa meningkatkan Pendapatan Asli Daerah sehingga didalam perencanaan untuk belanja modal tetap dianggarkan. Aset tetap yang dimiliki sebagai akibat adanya belanja modal merupakan persyaratan utama dalam pemenuhan kebutuhan pelayanan publik oleh pemerintah daerah. 
Penerimaan PAD yang semakin bertambah diharapkan mampu meningkatkan alokasi belanja modal pemerintah daerah sehingga berdampak pada kualitas pelayanan publik yang semakin baik. Senada dengan hal tersebut, penelitian yang dilakukan oleh Darwanto dan Yustikasari (2007) serta Tuasikal (2008) memperoleh hasil bahwa Pendapatan Asli Daerah (PAD) berpengaruh positif dan signifikan terhadap belanja modal. Namun terkadang peningkatan PAD tidak selalu diikuti dengan peningkatan anggaran belanja modal karena PAD banyak terserap untuk membiayai belanja lainnya. Penelitian yang dilakukan oleh Rizanda (2013) dan Paujiah (2012) memperoleh hasil bahwa pendapatan asli daerah tidak berpengaruh terhadap belanja modal. Hal ini disebabkan karena PAD yang diperoleh lebih banyak digunakan untuk membiayai belanja lainnya, seperti belanja pegawai dan keseharian pemerintah daerah. Penelitian yang dilakukan oleh Rian Septia Aditya Pradana (2016) dan Santika Adhi Karyadi (2017) memperoleh hasil bahwa bahwa PAD, Dana Perimbangan, dan Dana Alokasi Khusus berpengaruh positif dan signifikan terhadap Belanja Modal.

Perbedaan hasil pada penelitianpenelitian terdahulu seperti pada penelitian Darwanto dan Yustikasari (2007) dan Tuasikal (2008) dengan penelitian Rizanda (2013) dan Paujiah (2012) menarik perhatian penulis untuk meneliti kembali pengaruh pendapatan asli daerah terhadap belanja modal guna mengkonfirmasi hasil riset terdahulu. Bedanya, dalam penelitian ini menggunakan variabel independent Lain-lain Pendapatan Daerah yang Sah. Penelitian ini didasarkan pada keingintahuan peneliti tentang sejauhmana pengaruh ketiga variabel independent tersebut terhadap belanja modal Pemerintah Kabupaten Barito Timur.

\section{Studi Literatur}

Manajemen keuangan merupakan salah satu bagian utama dari ilmu manajemen. Banyak yang beranggapan bahwa manajemen keuangan hanya kegiatan catat mencatat uang secara akuntansi dan menjadi tanggung jawab bagian keuangan saja. Secara lebih luas pengertian manajemen keuangan adalah semua aktivitas organisasi didalam upaya mendapatkan, mengalokasikan, menggunakan dana organisasi secara efektif dan efisien. Pengertian ini mengalami berbagai perkembangan, berawal dari pengertian yang hanya sekedar mengutamakan kegiatan mendapatkan/memperoleh dana saja hingga mencakup kegiatan mendapatkan, cara menggunakan dana hingga pengelolaan terhadap aset (aktiva) perusahaan (Musthafa; 2017).

Kinerja keuangan adalah gambaran kondisi keuangan perusahaan pada suatu periode tertentu baik menyangkut aspek penghimpunan dana maupun penyaluran dana, yang biasanya diukur dengan indikator kecukupan modal, likuiditas, dan profitabilitas (Jumingan,2006:239). Kinerja keuangan perusahaan merupakan prestasi yang dicapai perusahaan dalam suatu periode tertentu yang mencerminkan tingkat kesehatan perusahaan tersebut (Sutrisno, 2009:53).

Menurut Permendagri Nomor 13 Tahun 2006 Pasal 1 ayat 9 menyebutkan bahwa Anggaran Pendapatan dan Belanja Daerah, selanjutnya disingkat APBD adalah rencana keuangan tahunan pemerintahan daerah yang dibahas dan disetujui bersama oleh pemerintah daerah dan DPRD, dan ditetapkan dengan peraturan daerah.

Pendapatan Asli Daerah merupakan tulang punggung pembiayaan daerah, oleh karenanya kemampuan melaksanakan ekonomi diukur dari besarnya kontribusi yang diberikan oleh Pendapatan Asli Daerah terhadap APBD, semakin besar kontribusi yang dapat diberikan oleh Pendapatan Asli Daerah terhadap APBD berarti semakin kecil ketergantungan pemerintah daerah terhadap bantuan pemerintah pusat.

Menurut Mardiasmo (2002:132) "Pendapatan asli daerah adalah penerimaan yang diperoleh dari sektor pajak daerah, retribusi daerah hasil perusahaan milik 
daerah, hasil pengelolaan kekayaan daerah yang dipisahkan, dan lain-lain pendapatan asli daerah. Undang-undang Nomor 33 tahun 2004 tentang perimbangan keuangan antara pemerintah pusat dan pemerintah daerah disebutkan bahwa sumber-sumber pendapatan daerah terdiri dari Pendapatan Asli Daerah, Bagi Hasil Pajak dan Bukan Pajak.

Pendapatan Asli Daerah terdiri dari

1. Pajak daerah adalah iuran wajib yang dilakukan oleh orang pribadi atau badan kepada daerah tanpa imbalan langsung yang seimbang, yang dapat dipaksakan berdasarkan peraturan perundangundangan yang berlaku yang digunakan untuk membiayai penyelenggaraan pemerintah daerah dan pembangunan daerah.

2. Retribusi daerah adalah pungutan daerah sebagai pembayaran atas jasa atau pemberian izin tertentu yang khusus disediakan dan atau diberikan oleh pemerintah daerah untuk kepentingan orang pribadi atau badan.

3. Hasil Pengelolaan Daerah Yang Sah

Selain pajak daerah dan retribusi daerah, bagian laba perusahaan milik daerah (BUMD) merupakan salah satu sumber yang cukup potensial untuk dikembangkan.

Dana Perimbangan merupakan dana yang bersumber dari penerimaan Anggaran Pendapatan dan Belanja Negara (APBN) yang dialokasikan kepada daerah untuk membiayai kebutuhan daerah. Dana Perimbangan disebut juga transfer atau grants. Transfer merupakan konsekuensi dari tidak meratanya keuangan dan ekonomi daerah. Selain itu tujuan transfer adalah mengurangi keuangan horizontal antar daerah, mengurangi kesenjangan vertical Pusat-Daerah, mengatasi persoalan efek pelayanan public antar daerah, dan untuk menciptakan stabilitas aktivitas perekonomian di daerah (Abdullah dan Halim 2003).

Undang-undang Nomor 33 tahun 2004 menjelaskan tentang Lain-lain Pendapatan asli Daerah yang sah, disediakan untuk menganggarkan penerimaan daerah yang tidak termasuk dalam jenis pajak daerah, dan hasil pengelolaan kekayaan daerah yang dipisahkan. Menurut Halim (2004), "Pendapatan ini merupakan penerimaan daerah yang berasal dari lain-lain milik pemerintah daerah." Jenis pendapatan ini meliputi objek pendapatan berikut:

Penerimaan pendapatan daerah yang terakhir ialah melalui pendapatan daerah yang sah, dimana pendapatan tersebut meliputi:

1. Hasil penjualan kekayaan daerah yang tidak dipisahkan

2. Jasa giro

3. Pendapatan bunga

4. Keuntungan selisih nilai tukar rupiah terhadap mata uang asing

5. Komisi, potongan, ataupun bentuk lain sebagai akibat dari penjualan dan/ atau jasa oleh Daerah.

Menurut Standar Akuntansi Pemerintah (SAP), pengertian belanja modal adalah pengeluaran yang dilakukan dalam rangka pembentukan modal yang sifatnya menambah aset tetap/inventaris yang memberikan manfaat lebih dari satu periode akuntansi, termasuk di dalamnya adalah pengeluaran untuk biaya pemeliharaan yang sifatnya mempertahankan atau menambah masa manfaat, serta meningkatkan kapasitas dan kualitas aset. Dalam hal ini pembelanjaan modal yang dimaksud dapat berupa tanah, peralatan dan mesin, gedung dan bangunan, jaringan, maupun dalam bentuk fisik lainnya, seperti buku, binatang dan lain sebagainya. Untuk mengetahui apakah suatu belanja dapat dimasukkan sebagai Belanja Modal atau tidak, maka perlu diketahui definisi aset tetap atau aset lainnya dan kriteria kapitalisasi aset tetap.

$$
\text { Belanja modal adalah suatu }
$$
pengeluaran yang dilakukan untuk menambah aset tetap atau investasi yang ada sehingga kan memberikan manfaatnya tersendiri pada periode tertentu. Dalam hal tersebut masuk ke dalam pembukuan akuntansi dengan kata lain belanja modal akan mempengaruhi posisi keuangan. 
Dalam SAP, belanja modal terdiri dari beberapa jenis belanja modal yang dikategori utama, diantaranya adalah :

1) Belanja Modal Tanah

Belanja modal tanah adalah pengeluaran/biaya yang digunakan untuk pengadaan / pembelian /pembebasan,

penyelesaian, balik nama dan sewa tanah, pengosongan, pengurugan, perataan, pematangan tanah, pembuatan sertifikat, dan pengeluaran lainnya sehubungan dengan perolehan hak atas tanah dan sampai tanah dimaksud dalam kondisi siap pakai.

2) Belanja Modal Peralatan dan Mesin Belanja modal peralatan dan mesin adalah pengeluaran/biaya yang digunakan untuk pengadaan/penambahan/penggantian, dan peningkatan kapasitas peralatan dan mesin, serta inventaris kantor yang memberikan manfaat lebih dari 12 (dua belas) bulan, dan sampai peralatan dan mesin dimaksud dalam kondisi siap pakai.

3) Belanja Modal Gedung dan Bangunan

Belanja modal gedung dan bangunan adalah pengeluaran/biaya yang digunakan untuk pengadaan/penambahan/penggantian, termasuk pengeluaran untuk perencanaan, pengawasan dan pengelolaan pembangunan gedung dan bangunan yang menambah kapasitas sampai gedung dan bangunan dimaksud dalam kondisi siap pakai.

4) Belanja Modal Jalan, Irigasi dan Jaringan

Belanja modal jalan, irigasi dan jaringan adalah pengeluaran/biaya yang digunakan untuk pengadaan/penambahan/penggantian /peningkatan pembangunan/ pembuatan serta perawatan, dan termasuk pengeluaran untuk perencanaan, pengawasan dan pengelolaan jalan irigasi dan jaringan yang menambah kapasitas sampai jalan irigasi dan jaringan dimaksud dalam kondisi siap pakai.

5) Belanja Modal Fisik Lainnya

Belanja modal fisik lainnya adalah pengeluaran/biaya yang digunakan untuk

pengadaan/penambahan/penggantian /peningkatan

pembangunan/pembuatan serta perawatan terhadap fisik lainnya yang tidak dapat dikategorikan ke dalam kriteria belanja modal tanah, peralatan dan mesin, gedung dan bangunan, dan jalan irigasi dan jaringan. Termasuk dalam belanja ini adalah belanja modal kontrak sewa beli, pembelian barang-barang kesenian, barang purbakala dan barang untuk museum, hewan ternak dan tanaman, buku-buku, jurnal ilmiah.

Menurut Darise (2008 : 141), Belanja Modal merupakan pengeluaran yang dilakukan dalam rangka pembelian, pengadaan atau pembangunan aset tetap berwujud yang mempunyai nilai manfaat lebih dari dua belas bulan untuk digunakan dalam kegiatan pemerintahan, seperti dalam bentuk tanah, peralatan mesin, gedung dan bangunan, jalan, irigasi dan jaringan, dan aset tetap lainnya.

\section{Metode Penelitian}

Jenis penelitian yang dilakukan oleh peneliti adalah penelitian berbentuk deskriptif kuantitatif, dimana penelitian ini akan menggambarkan fenomena data yang berlangsung selama 10 (sepuluh) tahun (dari 2010 sampai dengan 2019) di Pemerintah Daerah Kabupaten Barito Timur. Sumber data penelitian ini adalah Laporan Keuangan Pemerintah Daerah Kabupaten Barito Timur selama 10 (sepuluh) tahun (2010 sampai 2019) dengan menggunakan data, sebagai berikut :

1. Data kuantitatif yaitu data yang berupa angka-angka yang termuat di dalam Laporan Realisasi Anggaran yang berupa Data Pendapatan, Total Belanja, Pembiayaan Daerah dalam ringkasan laporan realisasi APBD Pemerintah 
Daerah Kabupaten Barito Timur Tahun 2010 sampai dengan 2019;

2. Data sekunder adalah data yang diperoleh dari pihak lain yaitu Data Realisasi APBD Kabupaten Barito Timur Tahun Anggaran 2010-2019 dan data Bartim Dalam Angka pada BPS Kabupaten Barito Timur;

3. Menggunakan regresi linear berganda dengan 3 (tiga) variabel independen yaitu pendapatan asli daerah (X1), dana perimbangan (X2) dan lain-lain pendapatan daerah yang sah (X3), dan 1 (satu) variabel dependen belanja modal (Y).

Populasi yang digunakan dalam penelitian ini adalah Laporang Keuangan Pemerintah Kabupaten Barito Timur dari Laporan Realisasi Anggaran Tahun 20102019.

Sampel yang digunakan dalam penelitian ini adalah :

1. Pendapatan Asli Daerah (X1) selama 10 (sepuluh) tahun, yaitu dari tahun 2010 sampai dengan 2019;

2. Dana Perimbangan (X2) selama 10 (sepuluh) tahun, yaitu dari tahun 2010 sampai dengan 2019;

3. Lain-lain Pendapatan Daerah yang Sah (X3) selama 10 (sepuluh) tahun, yaitu dari tahun 2010 sampai dengan 2019;

4. Belanja Modal (Y) selama 10 (sepuluh) tahun, yaitu dari tahun 2010 sampai dengan 2019.

Alat analisis yang digunakan adalah program statistik SPSS 24 for windows. Teknik analisis yang digunakan adalah uji asumsi klasik, uji regresi linier berganda dan uji simultan. Uji asumsi klasik terdiri atas uji normalitas, uji multikolinearitas, uji heteroskedastisitas, uji autokorelasi dan uji linearitas. Uji regresi linier berganda menggunakan uji statistik $F$ adalah untuk menguji joint hipotesa bahwa b1, b2 dan b3 secara simultan sama dengan nol. Jika F hitung > Ftabel dan nilai signifikasi $\mathrm{P}<0,05$ maka secara simultan variabel Pendapatan Asli Daerah, Dana Perimbangan dan Lail Lain Pendapatan Daerah yang Sah berpengaruh sinifikan terhadap Belanja Modal, sebalik jika F hitung < Ftabel dan Nilai signifikansi
$\mathrm{P}>0,05$, maka secara simultan Pendapatan Asli Daerah, Dana Perimbangan dan Lail Lain Pendapatan Daerah yang Sah tidak berpengaruh signifikan terhadap Belanja Modal dan uji statistik $t$ adalah jika $t$ hitung $>\mathrm{t}$ tabel dan nilai signifikasi $\mathrm{P}<0,05$ maka secara parsial variabel Pendapatan Asli Daerah, Dana Perimbangan dan Lail Lain Pendapatan Daerah yang Sah berpengaruh sinifikan terhadap Belanja Modal, sebalik jika $\mathrm{t}$ hitung $<\mathrm{t}$ tabel dan Nilai signifikansi $\mathrm{P}>0,05$, maka secara parsial Pendapatan Asli Daerah, Dana Perimbangan dan Lail Lain Pendapatan Daerah yang Sah tidak berpengaruh signifikan terhadap Belanja Modal..

\section{Hasil Penelitian dan Pembahasan}

Sampel penelitian pada Badan Pengelolaan Keuangan dan Aset Daerah adalah Laporan Realisasi Semester Keuangan Pemerintah Daerah Kabupaten Barito Timur selama 10 (sepuluh) tahun (2010 sampai 2019). Pengujian dilakukan dengan tingkat kepercayaan $95 \%$ atau tingkat signifikansi 0,05 . Untuk mengkaji kebenaran atas pengujian tersebut digunakan analisis hasil penelitian yang meliputi :

a. Uji Asumsi Klasik

Pengujian dengan uji asumsi klasik didapatkan bahwa uji hasil pengujian normalitas dengan menggunakan uji one sample kolmogorov-smirnov menunjukan nilai signifikansi sebesar 0,130, karena nilai sig > 0,05 maka data pada model regresi telah berdistribusi normal. Hasil uji multikolinieritas pengujian data menunjukan Variabel PAD memiliki nilai Tolerance sebesar 0,391 dan VIF 2,557; Dana Perimbangan memiliki tolerance sebesar 0,580 dan VIF 1,725; serta Lain-Lain PD yang Sah memiliki nilai Tolerance 0,525 dan VIF 1,905. Seluruh nilai Tolerance variabel independen $>0,1$ dan VIF $<10$ menunjukan tidak terdapat korelasi yang tinggi antara variabel independen.VIF dari hasil 
uji asumsi klasik masih diantara 110 jadi tidak terjadi multikolinieritas. Uji autokorelasi hasil pengujian menunjukan nilai Durbin Watson (DW) sebesar 2,077, dengan jumlah sampel data 20 , variabel independen $(\mathrm{k})=3$ dan probabilitas 0,05 , maka nilai DL sebesar 0,9976 dan DU sebesar 1,676. Maka 4-du $=4-1,676=$ 2,324 sehingga diperoleh nilai $\mathrm{Dl}$ $<$ DW < DU yakni : 1,676 < 2,077 $<2,324$, artinya bahwa dalam model regresi tidak terdapat masalah autokorelasi, dan dari uji heteroskedastisitas diketahui bahwa titik titik data menyebar diatas dan dibawah, titi-titik data tidak mengumpul hanya diatas atau dibawah saja, titik-titik data tidak membentuk pola bergelombang melebar kemudian menyempit dan melebar lagi serta penyebaran titik-titik data tidak berpola, maka disimpulkan tidak terjadi heteroskedastisitas.

b. Uji Analisis Regresi

$$
\text { Uji F (Simultan) }
$$

Berdasarkan hasil pengolahan data statistik diperoleh nilai $F$ hitung sebesar 30,557 adalah lebih besar dari Ftabel $=3,239$ dengan nilai signifikansi 0,000. Nilai signifikansi kurang dari taraf kesalahan 0,05 sehingga dapat dikatakan bahwa pendapatan asli daerah, dana perimbangan dan lain-lain pendapatan yang sah secara simultan berpengaruh signifikan terhadap belanja modal Pemerintah Kabupaten Barito Timur. Dengan demikian hipotesis pertama yang berbunyi pendapatan asli daerah, dana perimbangan dan lain-lain pendapatan daerah yang sah secara simultan berpengaruh signifikan terhadap belanja modal dapat dibuktikan.

Pengujian analisis regresi linier berganda dapat dijelaskan pada tabel 1 sebagai berikut:

Tabel 1. Uji Regresi Linear

\begin{tabular}{|c|c|c|}
\hline \multicolumn{3}{|c|}{ Coefficients $^{\mathrm{a}}$} \\
\hline \multirow[b]{2}{*}{ Model } & \multicolumn{2}{|c|}{$\begin{array}{l}\text { Unstandardized } \\
\text { Coefficients }\end{array}$} \\
\hline & B & $\begin{array}{l}\text { Std. } \\
\text { Error }\end{array}$ \\
\hline $\begin{array}{l}\text { (Con } \\
\text { stant) }\end{array}$ & $\begin{array}{l}1389389329 \\
0,000\end{array}$ & $\begin{array}{l}1341770357 \\
0,000\end{array}$ \\
\hline PAD & $\begin{array}{lr} & 1,44 \\
2 & \\
\end{array}$ & ,562 \\
\hline $\begin{array}{l}\text { Dana } \\
\text { Perimban } \\
\text { gan }\end{array}$ & ,146 & ,049 \\
\hline \begin{tabular}{lr}
\multicolumn{2}{r}{ Lain- } \\
Lain PD \\
yang Sah
\end{tabular} & ,358 & ,158 \\
\hline
\end{tabular}
2021

Sumber: Data Primer Diolah,

Dari hasil analisis seperti ditunjukkan dalam tabel di atas, maka dapat ditulis bentuk persamaan regresi sebagai berikut:

$$
\begin{aligned}
& \mathrm{Y}=\mathbf{- 1 3 8 9 3 8 9 3 2 9 0}+\mathbf{1 , 4 4 2} \mathrm{X} 1+ \\
& \mathbf{0 , 1 4 6} \mathrm{X2}+\mathbf{0 , 3 5 8 X 3}+\mathrm{e} \\
& \text { Untuk mengetahui pengaruh }
\end{aligned}
$$
masing-masing variabel independen terhadap variabel dependen dapat dilihat dari hasil regresi linear sebagai berikut:

1. Konstanta bernilai -13893893290 artinya apabila tidak terdapat pengaruh dari PAD, Dana Perimbangan dan Lain-Lain Pendapatan Daerah yang Sah, maka Belanja Modal akan bernilai negatif sebesar Rp 13.893.893.290,00;

2. Nilai koefisien PAD sebesar 1,442 artinya PAD berpengaruh positif terhadap Belanja Modal. Apabila PAD meningkat sebesar $\mathrm{Rp} 1$ sementara Dana Perimbangan dan Lain-Lain Pendapatan Daerah yang Sah bernilai konstan, maka Belanja Modal akan meningkat sebesar Rp 1,442 atau 1.442 sen;

3. Nilai koefisien Dana Perimbangan sebesar 0,146 artinya Dana Perimbangan berpengaruh positif terhadap Belanja Modal. Apabila Dana Perimbangan meningkat sebesar Rp 1 sementara PAD dan Lain-Lain Pendapatan Daerah yang Sah bernilai konstan, maka Belanja Modal akan 
meningkat sebesar Rp. 0,146 atau 146 sen;

4. Nilai koefisien Lain-Lain Pendapatan Daerah yang Sah sebesar 0,358 artinya Lain-Lain Pendapatan Daerah yang Sah berpengaruh positif terhadap Belanja Modal. Apabila Lain-Lain Pendapatan Daerah yang Sah meningkat sebesar $\mathrm{Rp} 1$ sementara PAD dan Dana Perimbangan yang Sah bernilai konstan (0), maka Belanja Modal akan meningkat sebesar Rp. 0,358 atau 358 sen.

Koefisien Determinasi hasil pengujian menunjukan nilai Adjusted $\mathrm{R}$ Square sebesar 0,824 yang berarti PAD, Dana Perimbangan dan Lain-Lain Pendapatan Daerah yang Sah dapat menjelaskan pengaruhnya terhadap belanja modal sebesar $82,4 \%$ sedangkan sisanya sebesar $17,6 \%$ dipengaruhi oleh variabel lain diluar variabel penelitian ini.

variabel yang berpengaruh dominan hasil pengujian menunjukan bahwa variabel pendapatan asli daerah adalah variabel yang memiliki koefisien beta yang paling besar dengan nilai koefisien beta sebesar 1,442, dana perimbangan memiliki nilai koefisien beta sebesar 0,146 dan lain lain pendapatan daerah yang sah memiliki nilai koefisien beta sebesar 0,358. Berdasarkan hasil perhitungan tersebut variabel pendaptan asli daerah adalah variabel yang paling dominan.

Dari hasil pengujian variabel variabel tersebut dapat dilihat pada skema sebagai berikut:

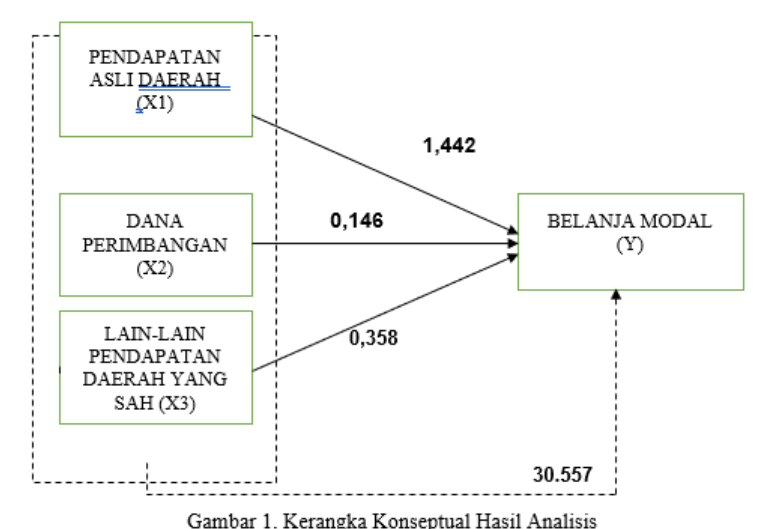

Gambar 1. Kerangka Konseptual Hasil Analisis

\section{Kesimpulan}

Berdasarkan hasil penelitian dan pembahasan, maka didapatkan beberapa kesimpulan sebagai berikut:

1. Berdasarkan hasil pengolahan data statistik, diperoleh nilai $\mathrm{F}$ hitung sebesar 30,557 adalah lebih besar dari Ftabel $=3,239$ dengan nilai signifikansi $\quad 0,000 . \quad$ Nilai signifikansi kurang dari taraf kesalahan 0,05 sehingga dapat dikatakan bahwa pendapatan asli daerah, dana perimbangan dan lain-lain pendapatan yang sah secara simultan berpengaruh signifikan terhadap belanja modal Pemerintah Kabupaten Barito Timur.

2. Pendapatan asli daerah secara parsial berpengaruh signifikan terhadap belanja modal Pemerintah Kabupaten Barito Timur. Hal ini ditunjukkan dengan nilai signifikansi kurang dari 5\% dan koefisien beta sebesar 1,442.

3. Dana perimbangan secara parsial berpengaruh signifikan terhadap belanja modal Pemerintah Kabupaten Barito Timur. Hal ini ditunjukkan dengan nilai signifikansi kurang dari 5\% dan koefisien beta sebesar 0,146.

4. Lain-lain pendapatan yang sah secara parsial berpengaruh signifikan terhadap belanja modal Pemerintah Kabupaten Barito Timur. Hal ini ditunjukkan dengan nilai signifikansi kurang dari 5\% dan koefisien beta sebesar 0,358.

5. Pendapatan asli daerah merupakan variabel penelitian yang paling dominan berpengaruh signifikan terhadap belanja modal Pemerintah Kabupaten Barito Timur yang ditunjukkan dengan nilai koefisien beta sebesar 1,442 .

Berdasarkan hasil analisis dan kesimpulan penelitian, maka dapat disampaikan beberapa saran sebagai berikut:

1. Pemerintah Kabupaten Barito Timur perlu lebih memaksimalkan 
pengelolaan potensi pendapatan asli daerah, dengan cara mengoptimalkan penerimaan dari potensi pendapatanya yang telah ada. Inisiatif dan kemauan Pemerintah Daerah sangat diperlukan dalam upaya peningkatan PAD. Peningkatan PAD bisa dilakukan Pemerintah Darah dengan cara melaksanakan secara optimal pemungutan pajak dan retribusi daerah sehingga dengan tingginya tingkat kemandirian daerah maka tingkat ketergantungan terhadap dana dari pusat makin berkurang.

2. Belanja Modal perlu terus ditingkatkan lagi dari tahun ketahun sesuai dengan Ditjen Bina Keuangan Daerah bahwa belanja modal harus mencapai $30 \%$ agar masyarakat yang ada di Bariito Timur semakin bisa menikmati pembangunan yang ada di Barito Timur.

\section{Daftar Pustaka}

Permatasari Isti. 2016. Pengaruh Pendapatan Daerah Terhadap Belanja Modal Pada Kabupaten/Kota Di Jawa Timur. Jurnal Ilmu dan Riset Akuntansi : Volume 5, Nomor 1, Januari 2016 : ISSN : 2460-0585.

UU RI. 2004. Undang-Undang Republik Indonesia Nomor 32 Tahun 2004 tentang Pemerintah Daerah

Suwarni, Sri. 2009. "Pengaruh Pendapatan Asli Daerah (PAD), LainlainPendapatan Yang Sah (LPS), Dana Alokasi Umum (DAU) DanDana Bagi Hasil (DBH) Terhadap Pengalokasian Anggaran BelanjaModal Pemerintah Daerah (Studi Empiris Pada PemerintahKabupaten/Kota Di Pulau Kalimantan)." Universitas Sebelas MaretSurakarta..
Yuliati. 2001. Analisis Kemampuan Keuangan Daerah dalam menghadapai Otonomi Daerah, Manajemen Keuangan Daerah. Yogyakarta: UPP YKPN.

Mardiasmo, 2004. Otonomi dan Manajemen Keuangan Daerah, Penerbit ANDI, Yogyakarta.

Mustafa, SE.2017. Manajemen Keuangan. Cetakan Pertama. Penerbit Andi:Yogyakarta.

Peraturan Menteri Dalam Negeri Nomor 13 Tahun 2006. Keuda.Kemendagri.go.id/produkh ukum/download/.../permendagrino-13-tahun-2006.

Peraturan Menteri Dalam Negeri Nomor 59 Tahun 2007. https://jdih.surabaya.go.id/pdfdoc/ permendagri-57.pdf.

Standar Akuntansi Pemerintah. 2011. www.djpk.depkeu.go.id/attach/po st-pp-standar-akuntansipemerintah/PP71.pdf.

Undang-Undang Nomor 33 Tahun 2004. Perimbangan Keuangan Antara Pemerintah Pusat dan Pemerintah Daerah. www.djpk.kemenkeu.go.id/p=367 